\title{
VOICE OUTCOMES AS A RESULTS OF VOICE THERAPY AFTER LOBECTOMY AND THYROIDECTOMY
}

\author{
Ana Bonetti ${ }^{1}$, Ivana Šimić ${ }^{2}$, Tamara Živković-Ivanović ${ }^{2}$ \\ ${ }^{1}$ Department of Logopedics, Faculty of Education and Rehabilitation Sciences, University of Zagreb, Zagreb; \\ ${ }^{2}$ Department of Otolaryngology, Head and Neck Surgery, Zagreb University Hospital Centre
}

SUMMARY - Voice disorders are among the most common complications of thyroid surgery. It is therefore advisable to continuously monitor and report the outcomes of voice rehabilitation among people who underwent thyroid surgery in order to recognize which specific clinical actions are necessary to give those patients the maximum chance to restore quality of life. The aim of this study was to examine the outcomes of voice therapy in 35 persons ( 26 women and 9 men) aged between 20 and 75 years after total thyroidectomy or lobectomy. Multidimensional voice assessment using the GRBAS scale, Voice Handicap Index questionnaire, and acoustic analysis was carried out before and after voice therapy, which included relaxation and breathing exercises, laryngeal massage, resonance therapy, and the employment of the digital compression method. Since the Wilcoxon Signed Ranks Test showed significant improvements in all voice parameters after voice therapy, voice rehabilitation seems to be the essential clinical activity for thyroid surgery patients who suffer from voice disorders postoperatively.

Key words: thyroid surgery, voice disorders, voice therapy

\section{Introduction}

Consequences of thyroid surgery may include postoperative dysphagia, hypocalcemia, hoarseness, shortness of breath, a lifelong need for replacement therapies, scarring in the operative area, and others, all of which have a potential to decrease postoperative quality of life $(1,2)$. Complications following thyroid surgery are more commonly associated with less experienced surgeons and advanced stages of thyroid disease (3).

In recent years, one of the more common postoperative consequences - recurrent or superior laryngeal nerve injury - has been reported less frequently, most likely due to the use of modern technologies in thyroid surgery such as intraoperative nerve monitoring, endoscopic surgery, and harmonic scalpels (4). Surgical in-

Corresponding author: Ana Bonetti, Department of Logopedics, Faculty of Education and Rehabilitation Sciences, University of Zagreb, Borongajska cesta 83f, Zagreb

E-mail: ana.bonetti@erf.unizg.hr juries of the laryngeal nerve are accompanied by dysphonia, which may also be associated with prelaryngeal musculature resections, intubation with possible arytenoid dislocation, and laryngeal tension. The incidence of both permanent and transient vocal cord paralysis following thyroid surgery is $1-26 \%$ (5).

Postoperative dysphonia can manifest as voice hoarseness, weakness, and breathiness, reduced phonation time, decreased volume, diplophonia, pitch breaks (6), and falsetto as a result of cricothyroid muscle being used in attempt to achieve glottal closure (7). One of the consequences of such great effort being invested is the feeling of discomfort and pain during voice production (8).

Dysphonia caused by unilateral injury of the lower laryngeal nerve with consequent paralysis or paresis of the vocal cords, whether transient or permanent, requires special attention and therapeutic procedures. Voice therapy is non-invasive and mainly used in all patients with dysphonia, with emphasis being placed on an early postoperative start so as to avoid later in- 
terventions, including laryngoplasty (installation of material into the vocal cord), thyroplasty, and nerve reinnervation, and to insure maximum alleviation of dysphonia (9). In most cases, vocal therapy focuses on combining the characteristics of direct or behavioral techniques focused on different subsystems of voice production together with indirect techniques, which include giving instructions on vocal hygiene, i.e. voiceharmful behaviors that should be avoided.

Since voice disorders following thyroidectomy are not uncommon (10), and due to the effect these disorders can have on quality of life deterioration (11), early postoperative detection of voice quality abnormalities as well as a rapid-onset and high-quality voice rehabilitation are of great importance in the successful rehabilitation of postoperative dysphonia. This paper is specifically aimed at presenting the results of early post-thyroidectomy vocal therapy. Its intention was to compare perceptual, acoustic, and subjective outcomes of speech therapy in patients who had undergone total or partial thyroidectomy and early multidimensional postoperative voice quality assessment.

The aim of this study was to examine outcomes and success rates of vocal therapy using multidimensional voice quality assessment on patients after lobectomy and thyroidectomy.

\section{Methods}

\section{Participants}

The study included 35 patients - 26 women and 9 men aged between 20 and 75 years (mean value 51.57; SD 11.66), who underwent thyroid surgery at the Department of Ear, Nose and Throat and Head and Neck Surgery of the Zagreb University Hospital Centre. The data were collected from September 2018 to September 2019. Total thyroidectomy was performed in 24 cases, and 11 patients underwent a lobectomy. Welldifferentiated thyroid cancer was pathohistologically verified in 22 patients, while follicular adenoma was discovered in 7 and benign goiter in 6 patients. Vocal cord paralysis occurred on the left side in 22 cases, whereas 13 patients had right-sided paralysis. Exclusion criteria were previous surgery in the head, neck, and chest area, radiation due to various malignant diseases, and fiber-optically proven preoperative paralysis of the vocal cords.
Subjects attended individual speech therapy for up to 6 months, during which sessions took place 3 times a week and each lasted 45 minutes. The main goal of conservative speech therapy was to achieve complete vocal cord adduction. Speech therapy in all cases included relaxation and breathing exercises, laryngeal massage, resonance therapy, and the digital compression method.

\section{Measurements}

Voice quality in all subjects was assessed using objective and subjective measurements at 2 points in time - prior to voice therapy and after its completion. The objective assessment included an acoustic analysis of the retained phonation of the vowel $/ \mathrm{a} /$ and was performed using the PRAAT program (version 6.1.10) to calculate jitter (JITT), shimmer (SHIM), and the ratio of noise and the harmonic part of the spectrum (HNR).

Perceptual assessment was performed using the GRBAS scale, completed by a speech therapist on a sample of spontaneous speech for each study participant (12). Each of the scale's parameters, including the Grade of Abnormality (G), Roughness (R), Breathiness (B), Asthenia (A), and Strain (S) were assessed on a four-grade scale $(0$ - normal voice, 1 - mild deviation, 2 - moderate deviation, and 3 - severe deviation).

The Croatian version of the VHI questionnaire (13) or the total value of the VHI (VHI-T) was used as an indicator of self-assessed voice quality. A VHI score between 0-30 reflected a minimal/mild VHI, 31-60 a moderate VHI, and between 61 and 120 a severe voice handicap (14).

\section{Data analysis}

Statistical analysis included descriptive analysis and the nonparametric Wilcoxon Signed Ranks Test. A statistical significance level of $95 \%(\mathrm{P}<0.05)$ was considered to be the significance limit for all statistical tests. Statistical analysis was performed with SPSS 17.0.

\section{Results}

The results of the descriptive analysis are shown in Tables 1-3. For the first measurement point (before voice therapy), the mean values of the observed acous- 
Table 1. Descriptive data (minimal/maximal values, mean and standard deviation) for the observed acoustic and subjective parameters of voice assessment before and after voice therapy for all participants of the study

\begin{tabular}{|l|l|l|l|l|l|l|l|l|l|}
\hline \multirow{2}{*}{} & \multirow{2}{*}{ N } & \multicolumn{4}{|c|}{ Before vocal therapy } & \multicolumn{4}{c|}{ After vocal therapy } \\
\cline { 3 - 9 } & & Min & Max & M & SD & Min & Max & M & SD \\
\hline JITT (\%) & 35 & 1.01 & 6.23 & 2.45 & 1.37 & 0.43 & 5.05 & 1.49 & 1.42 \\
SHIMM (dB) & 35 & 0.24 & 2.62 & 1.21 & 0.46 & 0.18 & 2.48 & 0.70 & 0.46 \\
HNR (dB) & 35 & 2 & 14 & 8.20 & 3.06 & 3 & 20 & 14.06 & 4.97 \\
G & 35 & 2 & 3 & 2.57 & 0.50 & 1 & 3 & 1.26 & 0.56 \\
R & 35 & 2 & 3 & 2.46 & 0.51 & 0 & 3 & 1.26 & 0.66 \\
B & 35 & 2 & 3 & 2.54 & 0.51 & 1 & 3 & 1.31 & 0.58 \\
A & 35 & 2 & 3 & 2.43 & 0.50 & 0 & 3 & 1.26 & 0.61 \\
S & 35 & 0 & 3 & 1.49 & 0.74 & 0 & 3 & 0.51 & 0.92 \\
VHI-T & 35 & 61 & 118 & 91.69 & 13.43 & 6 & 115 & 35.91 & 35.17 \\
\hline
\end{tabular}

Table 2. Descriptive data (minimal/maximal values, mean and standard deviation) for the observed acoustic and subjective parameters of voice assessment before and after voice therapy for participants of the study who underwent lobectomy

\begin{tabular}{|l|l|l|l|l|l|l|l|l|l|}
\hline \multirow{2}{*}{} & \multirow{2}{*}{ N } & \multicolumn{4}{|c|}{ Before voice therapy } & \multicolumn{5}{c|}{ After voice therapy } \\
\cline { 3 - 10 } & & Min & Max & M & SD & Min & Max & M & SD \\
\hline JITT (\%) & 11 & 1.03 & 5.12 & 2.48 & 1.347 & 0.43 & 5.00 & 1.50 & 1.56 \\
SHIMM (dB) & 11 & 0.24 & 2.62 & 1.17 & 0.63 & 0.18 & 2.48 & 0.81 & 0.68 \\
HNR (dB) & 11 & 2 & 14 & 8.00 & 3.95 & 3 & 20 & 13.00 & 5.88 \\
G & 11 & 2 & 3 & 2.36 & 0.51 & 1 & 2 & 1.18 & 0.41 \\
R & 11 & 2 & 3 & 2.45 & 0.52 & 1 & 2 & 1.18 & 0.41 \\
B & 11 & 2 & 3 & 2.64 & 0.51 & 1 & 2 & 1.18 & 0.41 \\
A & 11 & 2 & 3 & 2.27 & 0.47 & 1 & 2 & 1.18 & 0.41 \\
S & 11 & 1 & 2 & 1.36 & 0.51 & 0 & 2 & 0.36 & 0.81 \\
VHI-T & 11 & 69 & 113 & 91.82 & 14.30 & 6 & 111 & 38.64 & 37.80 \\
\hline
\end{tabular}

Table 3. Descriptive data (minimal/maximal values, mean and standard deviation) for the observed acoustic and subjective parameters of voice assessment before and after voice therapy for participants of the study who underwent thyroidectomy

\begin{tabular}{|l|l|l|l|l|l|l|l|l|l|}
\hline \multirow{2}{*}{} & \multirow{2}{*}{ N } & \multicolumn{4}{|c|}{ Before voice therapy } & \multicolumn{4}{c|}{ After voice therapy } \\
\cline { 3 - 9 } & & Min & Max & M & SD & Min & Max & M & SD \\
\hline JITT (\%) & 24 & 1.01 & 6.23 & 2.43 & 1.41 & 0.56 & 5.05 & 1.48 & 1.39 \\
SHIMM (dB) & 24 & 0.68 & 1.88 & 1.22 & 0.37 & 0.28 & 1.52 & 0.65 & 0.33 \\
HNR (dB) & 24 & 2 & 13 & 8.29 & 2.65 & 3 & 19 & 14.54 & 4.55 \\
G & 24 & 2 & 3 & 2.67 & 0.48 & 1 & 3 & 1.29 & 0.62 \\
R & 24 & 2 & 3 & 2.46 & 0.51 & 0 & 3 & 1.29 & 0.75 \\
B & 24 & 2 & 3 & 2.50 & 0.51 & 1 & 3 & 1.38 & 0.65 \\
A & 24 & 2 & 3 & 2.50 & 0.51 & 0 & 3 & 1.29 & 0.69 \\
S & 24 & 0 & 3 & 1.54 & 0.83 & 0 & 3 & 0.58 & 0.97 \\
VHI-T & 24 & 61 & 118 & 91.62 & 13.33 & 10 & 115 & 34.67 & 34.67 \\
\hline
\end{tabular}


Table 4. Test of the significance of differences in selected acoustic and subjective parameters in participants who underwent lobectomy before and after voice therapy

\begin{tabular}{|c|c|c|c|c|c|c|c|c|c|}
\hline & \multirow{3}{*}{$\mathrm{N}$} & \multicolumn{3}{|c|}{ Before voice therapy } & \multicolumn{3}{|c|}{ After voice therapy } & \multirow{3}{*}{$Z$} & \multirow{3}{*}{$\mathrm{p}$} \\
\hline & & \multicolumn{3}{|c|}{ Percentiles } & \multicolumn{3}{|c|}{ Percentiles } & & \\
\hline & & 25 th & 50th & 75 th & 25 th & 50th & 75 th & & \\
\hline JITT (\%) & 11 & 1.25 & 2.36 & 3.45 & 0.69 & 0.94 & 1.01 & -2.934 & 0.003 \\
\hline SHIMM (dB) & 11 & 0.92 & 1.10 & 1.34 & 0.40 & 0.54 & 0.99 & -2.669 & 0.008 \\
\hline $\operatorname{HNR}(\mathrm{dB})$ & 11 & 5 & 8 & 12 & 10 & 13 & 19 & -2.938 & 0.003 \\
\hline $\mathrm{G}$ & 11 & 2 & 2 & 3 & 1 & 1 & 1 & -3.127 & 0.002 \\
\hline $\mathrm{R}$ & 11 & 2 & 2 & 3 & 1 & 1 & 1 & -3.071 & 0.004 \\
\hline B & 11 & 2 & 3 & 3 & 1 & 1 & 1 & -2.889 & 0.003 \\
\hline A & 11 & 2 & 2 & 3 & 1 & 1 & 1 & -2.972 & 0.003 \\
\hline S & 11 & 1 & 1 & 2 & 0 & 0 & 0 & -2.810 & 0.005 \\
\hline VHI-T & 11 & 76 & 95 & 100 & 15 & 27 & 55 & -2.803 & 0.005 \\
\hline
\end{tabular}

tic parameters were above the reference values. These values decreased after the voice therapy, but still remained higher than the reference values.

Mean values of the GRBAS scale showed mildly to moderately impaired voice quality of study participants before voice therapy (15). After the therapy, the mean values $f$ the GRBAS scale were reduced to the category of mildly impaired voice quality on all perceptual parameters.

The other subjective assessment - self-assessment of the impact of voice quality on the quality of life with the VHI questionnaire - showed the greatest pre- and post-therapy changes: study participants reported a strong impact of impaired voice quality on the quality of life in the pre-therapy self-assessment, but the same impact was reported as moderate in the post-therapy self-assessment (14).

The statistical significance of the differences in the mean values of the selected parameters of multidimensional assessment before and after voice therapy was tested by the Wilcoxon signed-rank test (Tables 4-5). The Wilcoxon test showed significantly better results after the therapy on all of the observed variables, both in participants who underwent lobectomy (Table 4) and in participants who underwent thyroidectomy (Table 5).

Descriptive data of the Wilcoxon test for patients who underwent lobectomy with the associated $Z$ values and their significance level are shown in Table 4. The comparison of the median values before and after voice therapy showed a decrease in jitter (from 2.36\% to $0.94 \%$ ) and shimmer (from $1.10 \mathrm{~dB}$ to $0.54 \mathrm{~dB}$ ), and an increase of the median value of the harmonicto-noise ratio (HNR) from $8 \mathrm{~dB}$ to $14 \mathrm{~dB}$. The medians on the GRBAS scale showed a decrease in all of its parameters at the second measuring point, indicating perceptually better voice quality after the therapy. Finally, VHI self-assessment showed a median decrease in overall score from 95 before voice therapy to 27 after voice therapy, indicating its beneficial bio-psychosocial effect, i.e. a reduction in the impact of the impaired voice quality on the quality of life from an average of strong to an average of mild. It should be noted that the changes in all of the observed parameters (acoustic and subjective) were statistically significant after the voice therapy.

Descriptive data of the Wilcoxon test for patients who underwent thyroidectomy with the associated $Z$ values and their significance level are shown in Table 5. This group of study participants also presented a decrease of median values after vocal therapy in jitter (from $2.11 \%$ to $0.92 \%$ ) and shimmer (from $1.16 \mathrm{~dB}$ to $0.59 \mathrm{~dB}$ ), as well as an increase in the median value of HNR from $8 \mathrm{~dB}$ to $16 \mathrm{~dB}$. The medians on the GRBAS scale again showed perceptually better voice quality after vocal therapy, given the decrease in all observed perceptual parameters. As in the group of participants who underwent lobectomy, in participants who underwent thyroidectomy the median of the total VHI score decreased from 84.25 pre-therapy, to 19.00 post- therapy, again indicating a successful reduction in bio-psycho-social impact of impaired voice quality on the quality of life from an average of strong to an average 
Table 5. Test of the significance of differences in selected acoustic and subjective parameters in participants who underwent thyroidectomy before and after voice therapy

\begin{tabular}{|c|c|c|c|c|c|c|c|c|c|}
\hline & \multirow{3}{*}{$\mathrm{N}$} & \multirow{2}{*}{\multicolumn{3}{|c|}{$\begin{array}{c}\text { Before vocal therapy } \\
\text { Percentiles }\end{array}$}} & \multicolumn{3}{|c|}{ After vocal therapy } & \multirow{3}{*}{$\mathrm{p}$} & \multirow{3}{*}{ Z } \\
\hline & & & & & & Percer & & & \\
\hline & & 25 th & 50 th & 75 th & 25 th & 50th & 75 th & & \\
\hline JITT (\%) & 24 & 1.36 & 2.11 & 3.06 & 0.69 & 0.92 & 0.98 & 0.000 & -4.286 \\
\hline SHIMM (dB) & 24 & 0.91 & 1.16 & 1.52 & 0.39 & 0.59 & 0.90 & 0.000 & -4.286 \\
\hline $\operatorname{HNR}(\mathrm{dB})$ & 24 & 7 & 8 & 10 & 12.25 & 16 & 18 & 0.000 & -4.296 \\
\hline G & 24 & 2 & 3 & 3 & 1 & 1 & 1 & 0.000 & -4.231 \\
\hline $\mathrm{R}$ & 24 & 2 & 2 & 3 & 1 & 1 & 1 & 0.000 & -4.179 \\
\hline B & 24 & 2 & 2.50 & 3 & 1 & 1 & 2 & 0.000 & -3.946 \\
\hline A & 24 & 2 & 2.50 & 3 & 1 & 1 & 2 & 0.000 & -4.041 \\
\hline S & 24 & 1 & 1.50 & 2 & 0 & 0 & 1 & 0.000 & -3.906 \\
\hline VHI-T & 24 & 84.25 & 94.50 & 96.75 & 15.25 & 19 & 35 & 0.000 & -4.288 \\
\hline
\end{tabular}

of mild due to voice therapy. Once again, the changes in all of the observed parameters (acoustic and subjective) were statistically significant after the performed vocal therapy.

\section{Discussion}

Because the risk of dysphonia is higher after thyroidectomy than after lobectomy (17), one could expect that voice therapy outcomes will be more modest among participants who underwent thyroidectomy than among participants who underwent lobectomy. However, statistical analysis of the data indicated that, despite differences in surgical intervention and associated risks for voice quality, the two groups of participants achieved equally successful acoustic, perceptual, and self-assessment results after voice therapy. What the study participants had in common was early postoperative involvement in voice therapy, as well its content and dynamics. The combination of relaxation and breathing exercises, laryngeal massage, resonant therapy, and digital compression was evident in most study participants to favor vocal cord adduction, i.e. reduction of voice weakness and breathiness, which are noticeable before therapy due to vocal cord paralysis (18); voice therapy facilitated the movement of the vocal cords towards the medial line of the glottis and thus enabled glottal constipation, so the voices were perceived as less breathy, which was reflected as an improvement in the values of the observed acoustic parameters, especially HNR.
Similar conclusions have already been reported by Žunić et al. (2017), who observed a decrease in the noise-to-harmonic ratio (NHR) after voice nerve therapy in patients with recurrent laryngeal nerve injury (19). Cantarella et al. (2010) also observed a decrease in the NHR three months after voice therapy in patients with vocal cord paralysis and concluded that the therapy was able to achieve minimal spontaneous glottal compensation (20). Positive changes in voice quality after voice therapy have been documented in several other reports: Schindler et al. (2008) and Mattioli et al. (2011) reported statistically significant differences in acoustic parameters (jitter, shimmer, and NHR), perceptual assessment of voice quality (GRBAS scale), and in self-assessment of the impact of the voice quality on the quality of life (VHI questionnaire) before and after vocal therapy in patients with unilateral vocal fold paralysis $(7,21)$. Given the multiple reports of statistically significant improvements in the voice quality in patients with vocal cord paralysis after voice therapy, and especially improvements in quality of life associated with voice quality, voice therapy in these individuals appears to be a justified and often highly achievable clinical activity.

\section{Conclusion}

The crucial elements of therapy work with patients indicated for thyroid surgery have been shown to be a multidisciplinary approach throughout the whole intervention and early diagnosis of possible dysphonia 
(very soon after surgery) using a multidimensional approach $(22,23)$. Since self-assessment fails to show significant correlation with perceptual assessment of experts in most cases, the patient's feelings and attitudes towards the voice disorder and its impacts on quality of life should also be taken into consideration (24). The results of this study as well as previous research on multidisciplinary treatment of the diseases that need thyroid surgery, emphasize teamwork among general practitioners, ENT specialists, and speech therapists as a key element that enables the fastest accomplishment of the final interventional goal: to restore the highest achievable quality of life of patients following thyroid surgery in the shortest possible time.

\section{References}

1. Kusić Z, Prgomet D. Karcinom štitne i doštitne žljezde. In: Prgomet D. Tumori glave i vrata. Zagreb: Medicinska naklada. 2019. p.262-73.

2. Radivojević RC, Prgomet D, Markesić J, Ezgeta C. Hypocalcaemia after thyroid surgery for differentiated thyroid carcinoma: preliminary study report. Coll Antropol. 2012;36 Suppl 2:73-8.

3. Prgomet D, Bilić M, Kovac L, Hutinec Z, Topić I. Lokalno invazivni papilarni karcinom štitnjače-naša iskustva [Locally invasive papillary thyroid cancer--our experience]. Lijec Vjesn. 2012;134(9-10):266-70.

4. Prgomet D, Janjanin S, Bilić M, Prstačić R, Kovac L, Rudeš M, et al. A prospective observational study of 363 cases operated with three different harmonic scalpels. Eur Arch Otorhinolaryngol. 2009; 266(12):1965-70.

5. Jeannon JP, Orabi AA, Bruch GA, Abdalsalam HA, Simo R. Diagnosis of recurrent laryngeal nerve palsy after thyroidectomy: a systematic review. Int J Clin Pract. 2009; 63(4):624-9.

6. Boone DR, McFarlane SC, Von Berg SL. The voice and voice therapy, 7th edition. Boston: Allyn \& Bacon; 2005.

7. Schindler A, Bottero A, Capaccio P, Ginocchio D, Adorni F, Ottaviani F. Vocal improvement after voice therapy in unilateral vocal fold paralysis. J Voice. 2008; 22(1):113-8.

8. Miller S. Voice therapy for vocal fold paralysis. Otolaryngol Clin North Am. 2004;37(1):105-19.

9. D'Alatri L, Galla S, Rigante M, Antonelli O, Buldrini S, Marchese MR. Role of early voice therapy in patients affected by unilateral vocal fold paralysis. J Laryngol Otol. 2008;122 (9):936-41.
10. Page C, Zaatar R, Biet A, Strunski V. Subjective voice assessment after thyroid surgery: a prospective study of 395 patients. Indian J Med Sci. 2007;61(8):448-54.

11. Rohde SL, Wright CT, Muckala JC, Wiggleton J, Rousseau B, Netterville JL. Voice quality after recurrent laryngeal nerve resection and immediate reconstruction. Otolaryngol Head Neck Surg. 2012;147(4):733-6.

12. The Japan Society of Logopedics and Phoniatrics. Voice Examination Methods. Tokyo: Interna;1979.

13. Bonetti A, Bonetti L. Cross-cultural adaptation and validation of the Voice Handicap Index into Croatian. J Voice. 2013; 27(1):130.e7-130.e14.

14. Jacobson BH, Johnson A, Grywalski C, Silbergleit A, Jacobson $\mathrm{G}$, Benninger MS, et al. The Voice Handicap Index (VHI): development and validation. Am J Speech Lang Pathol. 1997;6: 66-70.

15. Jesus LM, Tavares AI, Hall A Cross-Cultural Adaption of the GRBAS and CAPE-V Scales for Portugal and a New Training Programme for Perceptual Voice Evaluation. In: Fernandes F. editors. Advances in Speech-language Pathology. IntechOpen. 2017. p. 221-36.

16. Teixeira J, Oliveira C, Lopes C. Vocal Acoustic Analysis - Jitter, Shimmer and HNR Parameters. Procedia Technology. 2013; 9:1112-22.

17. Ryu J, Ryu YM, Jung YS, Kim SJ, Lee YJ, Lee EK, et al. Extent of thyroidectomy affects vocal and throat functions: a prospective observational study of lobectomy versus total thyroidectomy. Surgery. 2013;154(3):611-20.

18. Blatančić G, Bonetti A, Živković - Ivanović T. Objektivna i perceptivna procjena kvalitete glasa kod osoba s jednostranom paralizom glasnice. Logopedija. 2017;7(1):1-5.

19. Junuzovic Zunic L, Ibrahimagic A, Altumbabic S, Umihanic S, Izic B. Improving Voice Outcomes After Injury to the Recurrent Laryngeal Nerve. Iranian Rehabilitation Journal. 2017; 15(4):399-406.

20. Cantarella G, Viglione S, Forti S, Pignataro L. Voice therapy for laryngeal hemiplegia: the role of timing of initiation of therapy. J Rehabil Med. 2010;42(5):442-6.

21. Mattioli F, Bergamini G, Alicandri-Ciufelli M, Molteni G, Luppi MP, Nizzoli F, et al. The role of early voice therapy in the incidence of motility recovery in unilateral vocal fold paralysis. Logoped Phoniatr Vocol. 2011;36(1):40-7.

22. de Pedro Netto I, Fae A, Vartanian JG, Barros AP, Correia LM, Toledo RN, et al. Voice and vocal self-assessment after thyroidectomy. Head Neck. 2006;28(12):1106-14.

23. Yu WV, Wu CW. Speech therapy after thyroidectomy. Gland Surg. 2017;6(5):501-9.

24. Misono S, Merati AL. Evidence-based practice: evaluation and management of unilateral vocal fold paralysis. Otolaryngol Clin North Am. 2012;45(5):1083-1108. 
Sažetak

\title{
ISHODI GLASOVNE TERAPIJE NAKON LOBEKTOMIJE I TOTALNE TIREOIDEKTOMIJE
}

\author{
A. Bonetti, I. Šimić i T. Živković-Ivanović
}

Poremećaji glasa su među najčešćim posljedicama operacije štitne žlijezde. Stoga je preporučljivo kontinuirano izvještavati o rezultatima rehabilitacije glasa kod ljudi koji su prošli operaciju štitnjače, kako bi se prepoznalo koje su specifične kliničke radnje potrebne da bi se tim pacijentima pružila maksimalna šansa za vraćanje prijašnje kvalitete života. Cilj ovog istraživanja bio je ispitati rezultate glasovne terapije 35 osoba (26 žena i 9 muškaraca) u dobi između 20 i 75 godina, nakon lobektomije ili totalne tireoidektomije štitne žlijezde. Multidimenzionalna procjena glasa putem GRBAS ljestvice, upitnika Indeks vokalnih teškoća i akustičke analize provedena je prije i nakon terapije glasa, koja je uključivala vježbe opuštanja i disanja, masažu larinksa, rezonantnu terapiju i primjenu metode digitalne kompresije. Budući da je primjena Wilcoxonovog testa pokazala značajna poboljšanja u mjerenim parametrima nakon terapije glasa, čini se da je rehabilitacija glasa ključna klinička aktivnost za pacijente s operacijom štitne žlijezde kod kojih je postoperativno dijagnosticiran poremećaj glasa.

Ključne riječi: bolesti štitne žlijezde, poremećaji glasa, glasovna terapija 